\title{
Possible adaptation measures of agriculture sector in the Nile Delta to climate change impacts
}

\author{
S. M. Attaher ${ }^{1}$, M. A. Medany ${ }^{1}$, and A. F. Abou-Hadid ${ }^{2}$ \\ ${ }^{1}$ Central Laboratory for Agricultural Climate (CLAC), Agricultural Research Center (ARC), \\ Ministry of Agriculture and Land Reclamation, Egypt \\ ${ }^{2}$ Agricultural Research Center (ARC), Ministry of Agriculture and Land Reclamation, Egypt
}

Received: 30 December 2008 - Revised: 5 February 2009 - Accepted: 20 February 2009 - Published: 13 October 2009

\begin{abstract}
The overall agricultural system in the Nile Delta region is considered as one of the highest intensive and complicated agriculture systems in the world. According to the recent studies, the Nile Delta region is one of the highly vulnerable regions in the world to climate change. Sea level rise, soil and water degradation, undiversified crop-pattern, yield reduction, pests and disease severity, and irrigation and drainage management were the main key factors that increased vulnerability of the agriculture sector in that region. The main objective of this study is to conduct a community-based multi-criteria adaptation assessment in the Nile Delta using a preset questionnaire. A list of possible adaptation measures for agriculture sector was evaluated. The results indicated that the Nile Delta growers have strong perceptions to act positively to reduce the impacts of climate change. They reflected the need to improve the their adaptive capacity based on clear scientific message with adequate governmental support to coop with the negative impacts of climate change.
\end{abstract}

\section{Introduction}

The Nile Delta is most important agricultural region in Egypt has about 1.8 million ha of the total cultivated area of about 3.36 million ha, and about $93 \%$ of the total Nile Delta land is "old land". The overall agricultural system in the Nile Delta is considered as one of the highest intensive and complicated agriculture systems in the world. The percentage of the total annual cropped area is averaged from 150 to $180 \%$ from the total cultivated land area, and contributed $65 \%$ of the total national agricultural production. IPCC (2001) reported that agriculture sector in the Nile Delta is highly vulnerable to climate change. The most likely result of climate change is a rise in global average temperature, which would in turn cause sea-level rise (SLR), and $12-15 \%$ of the existing agricultural land in the Nile Delta could be lost (Abd El-Wahab, 2005).

Generally, agriculture in Egypt is less sensitive to climate variability, due to the reliance on irrigated agriculture system. Whereas, the high vulnerability of agriculture system in Egypt is attributed to the current critical situation of water consumption in agriculture (Abou Zeid, 2002), the continues degradation of the fertility and the quality of the old

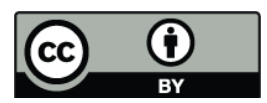

Correspondence to: S. M. Attaher (sattaher2001@yahoo.com) lands (Amer et al., 1997), salinity problems and water table logging, the estimated reduction and changes in crops productivity, the continues reduction in the size of land ownership (CAPMAS, 2001), and the socio-economical factors and pressures related to the agriculture community and agricultural production chain (Abou-Hadid, 2009). Medany and Attaher (2009) reported that the northern part of the Nile Delta could be the highest vulnerable sub-region in the Nile Delta due to the sea-level rise, soil and water degradation, limited crop pattern, yield reduction, and low efficiency of irrigation and drainage management. Urbanization and reduction in the size of land holdings were the most remarkable sources of vulnerability in the south Nile Delta sub-region. The high vulnerability of agricultural sector in the Nile Delta region put it in the top of priority of adaptation plans. Medany et al. (2007) concluded that designing adaptation strategy for agriculture sector should consider the simple and low cost adaptation measures, that may be inspired from traditional knowledge, and meet local conditions and compatible with sustainable development requirements. Setting a definition of future agenda and needs for increasing the adaptive capacity of agricultural sector, is one of the problems that face the agriculture scientific community. The climate change adaptation of the agricultural systems in Egypt could be studied and analyzed according to scientific bases, statistics, models, and policies. Whereas, encouraging the involvement of

Published by Copernicus Publications. 


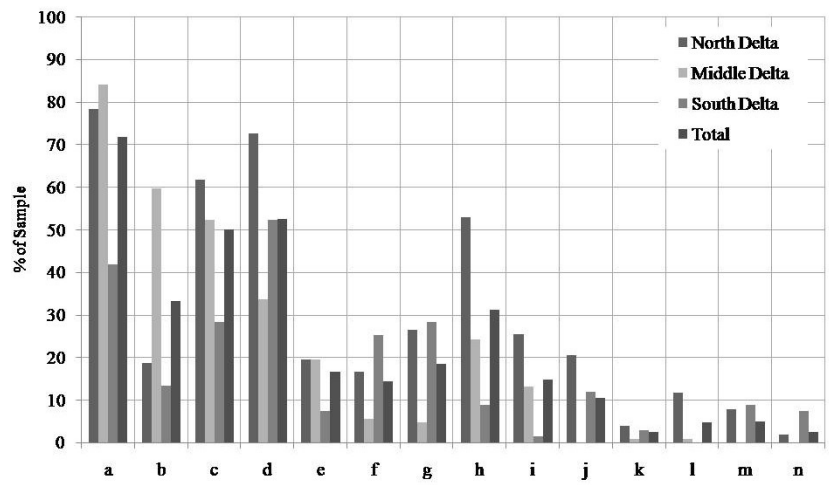

Figure 1. The proposed adaptation measures by the questioned farmers, and its representation values \%, over the Nile Delta sub-regions $(\mathrm{a}=$ changing cultivars $[\mathrm{S}], \mathrm{b}=$ changing crop pattern $[S], c=$ changing sowing dates $[\mathrm{M}], \mathrm{d}=$ increasing irrigation requirements $[\mathrm{M}], \mathrm{e}=$ changing the current irrigation systems $[\mathrm{S}]$, $\mathrm{f}=$ changing fertilization requirements $[\mathrm{M}], \mathrm{g}=$ modifying plant protection programs $[\mathrm{M}], \mathrm{h}=$ improving drainage systems $[\mathrm{S}]$, $\mathrm{i}=$ recycling agricultural drainage water in irrigation $[S], j=$ using compost $[\mathrm{M}], \mathrm{k}=$ cultivate the land one season and left it to rest in the second season $[\mathrm{M}], 1=$ replace the current fertilizers by soil conditioners $[\mathrm{M}], \mathrm{m}=$ leave the current cultivated land and move to reclaim new land $[\mathrm{S}], \mathrm{n}=$ leave the agri-business and find other carrier $[\mathrm{C}])$.

the agricultural stakeholders in adaptation planning, analyzing, and evaluating could improve the criteria of the resulted measures, and orient it in the directions of the actual local conditions. The goal of this study is to conduct a communitybased multi-criteria adaptation assessment in the Nile Delta. The main issues of the assessment were; (i) the acceptable options of adaptations at farmers' level, (ii) insurance and financial systems of adaptation, and (iii) the adaptation to land loss in the North Delta due to SLR.

\section{Materials and methods}

The proposed adaptation measures under assessment were based on the main key points affecting the vulnerability of the agriculture system under the projected climatic changes of Medany and Attaher (2009). The community-based pilot assessment is performed using a preset questionnaire. The survey questionnaire covered five main groups of adaptation measures of (i) structural measures [S], (ii) management measures [M], (iii) economical measures [E], (iv) social measures $[\mathrm{C}]$, and $(\mathrm{v})$ political measures $[\mathrm{P}]$. The surveys were conducted in 18 pilot locations in the Nile Delta. While, the Nile Delta was classified into three sub-regions of northern, middle and southern Nile Delta. The survey covered 160 samples in northern Nile Delta, 142 samples in middle Nile Delta, and 77 samples in southern Nile Delta, by overall samples of 379. The samples were taken randomly, and represent local farmers of each sub-region. The education level of $94 \%$

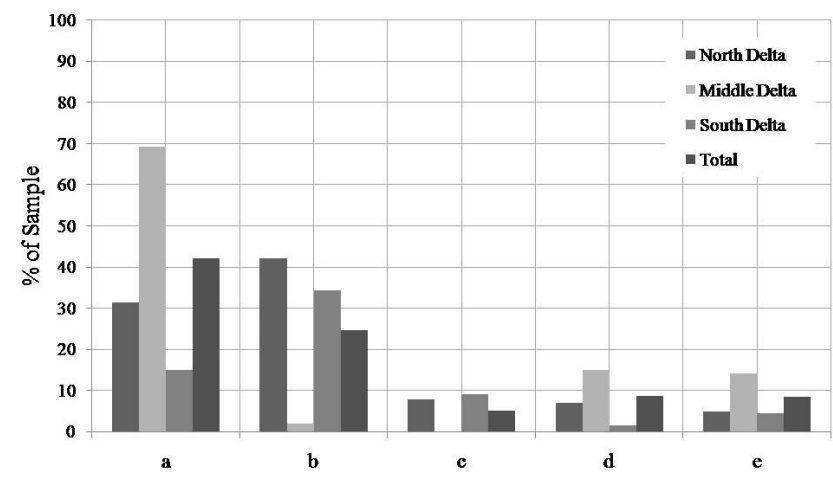

Figure 2. The farmers' perceptions of the financial and insurance systems for agriculture sector adaptation, and its representation values $\%$, over the Nile Delta sub-regions. ( $a=$ the government should handle the whole problem $[\mathrm{E}], \mathrm{b}=$ establishing farmers' cooperative-fund $[\mathrm{E}], \mathrm{c}=$ sharing in a governmental insurance box for future environmental hazards $[E], d=$ climate-hazards tax on crops prices $[\mathrm{E}], \mathrm{e}=$ establishing a special insurance system in insurance companies [E]).

the total sample ranged from without degree to university degree.

\section{Results}

Figure 1 presents the most efficient adaptation measures, according to farmers' perceptions, to reduce the negative impacts of climate change (warmer and dryer climate) over cultivation systems in the Nile Delta. More than $70 \%$ of the total sample considered that "changing cultivars" is the most important adaptation measure for agriculture systems in the Nile Delta. Whereas, "increasing irrigation requirements" and "changing sowing dates" came in the next level of adaptation priorities. The figure reflects the variation in farmers' perception in the three sub-regions of the Nile Delta, this variation is attributed to the variations in agro-ecosystems and keys of vulnerability of each sub-region addressed in Medany and Attaher (2009).

Establishing insurance and financial systems to overcome the unfavorable weather conditions impacts over agriculture production, and/or sustain the required resources for adaptation of the agriculture sector, is important emerging issue in adaptation planning. Figure 2 presents the results of the second section of the assessment, which investigated the farmers' perceptions towards the possible insurance and financial systems for adaptation. Average results for the Nile Delta region reflect the high dependency of about one half of the farmers on the government in handling the insurance and the financial loads under current and future conditions. Whereas, the other half of the sample believe that they have to find suitable solutions for this critical problem, through farmers' cooperative funds, special taxes, and private sector cooperation. 
Table 1. Farmers perception for alternative land area and governmental stimulations required to replace their current farms of old land in the Nile Delta by new farms of new reclaimed land in the Upper Egypt.

\begin{tabular}{|c|c|c|c|c|}
\hline & Northern Nile Delta & Middle Nile Delta & Southern Nile Delta & Total \\
\hline \multicolumn{5}{|l|}{ Acceptance of land replacement } \\
\hline- No & $83 \%$ & $85 \%$ & $73 \%$ & $82 \%$ \\
\hline- Yes & $17 \%$ & $15 \%$ & $27 \%$ & $18 \%$ \\
\hline \multicolumn{5}{|l|}{ Alternative land area } \\
\hline - Same old land area & $0 \%$ & $0 \%$ & $14 \%$ & $4 \%$ \\
\hline-1.5 of the old land area & $6 \%$ & $0 \%$ & $7 \%$ & $4 \%$ \\
\hline - Twice of old land area & $94 \%$ & $100 \%$ & $57 \%$ & $85 \%$ \\
\hline \multicolumn{5}{|l|}{ Governmental stimulations } \\
\hline - Subsidies on production inputs & $65 \%$ & $81 \%$ & $64 \%$ & $70 \%$ \\
\hline - Long term loan for land reclamation & $24 \%$ & $13 \%$ & $21 \%$ & $19 \%$ \\
\hline $\begin{array}{l}\text { - Marketing contracts with private sec- } \\
\text { tor, under governmental supervision }\end{array}$ & $12 \%$ & $6 \%$ & $14 \%$ & $11 \%$ \\
\hline
\end{tabular}

Replacing the current agriculture old land in the Nile Delta, by new reclaimed land, could be one of the possible and impressive adaptation measures to coop with the impact of SLR and soil salinity and degradation, which are projected to threaten the Nile Delta region under climate change conditions. Therefore, the current assessment investigated the farmers' reactions with this measure, by asking them if they accept to replace the farms in old land by an alternative farms in new reclaimed land in the Upper valley of Nile through a governmental program. And if they accept this offer, what is the appropriate area of the new land that should be offered by the program in order to meet the old land productivity. Additionally, the farmers were asked about the governmental stimulations that should be offered by the land replacement program in order to encourage the farmers to replace their lands. The results summarized in Table 1 indicated that about three quarters of the farmers refuse to replace their current old land by reclaimed land. This high percent of refusal is attributed to the low productivity of the reclaimed lands compared to the productivity of the old lands, the high cost of agriculture management and production in reclamation regions, and the difficulties and complications related to marketing and governmental programs. For the same reason of productivity reduction in reclaimed land, most of the farmers, who accept land-replacement, believe that the area of reclaimed land should be the twice of the area of the old land. Moreover, they indicate the "Subsidies on production inputs" as the most important governmental stimulations, which should be addressed under the governmental program of land replacement.

\section{Conclusions}

The current assessment indicated that farmers have strong perceptions to act positively to reduce the impact of climate change. This positive perception is reflected in the farmers' higher tendency to adopt structural adaptation-measures, which are characterized by high initial cost, more efficient at short time, and high uncertainty. Whereas, management adaptation-measures were the second proposed measures by the farmers, and these types of measures are characterized by lower initial cost, efficient at medium to long time scale, and lower uncertainty. Furthermore, although community engagement is very important for adaptation planning, the scientific evaluation should be taken into account to set more practical list of adaptation measures. The indicated farmers' perceptions in this assessment reflected the need to improve their adaptive capacity, in order to prepare this community to act more dynamically to face the negative impacts of climate change in agricultural systems. This improvement basically requires clear scientific message and governmental support.

Acknowledgements. The research reported in this paper was a part of the regional assessment of the FP6 project of "Adaptation of Agriculture in European Regions at Environmental Risk under Climate Change (ADAGIO)" (http://www.adagio-eu.org).

Edited by: E. Koch

Reviewed by: two anonymous referees 


\section{References}

Abd El-Wahab, H. M.: The impact of geographical information system on environmental development, M.Sc. Thesis, Fac. of Agric., Al-Azhar Univ., Cairo, unpublished, 2005.

Abou-Hadid, A. F.: Climate change and the Egyptian agriculture conundrum, Proceeding of the Ninth International Conference of Dryland Development, "Sustainable Development in the Drylands- Meeting the challenges of global climate change", 7 10 November 2008, Alexandria, Egypt, 2009.

Abou Zeid, K.: Egypt and the World Water Goals, Egypt statement in the world summit for sustainable development and beyond, Johannesburg, 2002.

Amer, F. A. I, Aboushal, A. A., and Kamel, M. W.: Soil Vulnerability to reuse of drainage and reclaimed waste in irrigation, Int. Symposium on Salt Affected Soils, Cairo, Egypt, 22-26 September 1997.
CAPMAS: Agricultural Census of 1990/2000, Central Agency for Public Mobilization and Statistics, 2001.

IPCC: Climate change 2001: Impact, Adaptation and Vulnerability, Contribution of Working Group II to the Third Assessment Report of the IPCC, Cambridge Univ. Press, Cambridge, UK, 2001.

Medany, M. A. and Attaher, S. M.: Vulnerability Assessment of agriculture sector in the Delta Region, Proc. of the first international conference on Environmental Studies and Research "Natural Resources and Sustainable Development", 7-9 April, Sadat Academy of Environmental Science, Minofya, Egypt, 2009.

Medany, M. A., Attaher, S. M., and Abou-Hadid, A. F.: Socioeconomical analysis of agricultural stakeholders in relation to adapting capacity to climate change in Egypt, Proc. of the International Cconference on "Cclimate Change and their Impacts on Costal Zones and River Deltas", Alexandria-Egypt, 23-25 April, 2007. 